\title{
Quality Distance Education for Early Childhood During the Corona Pandemic: The Perceptions of Female Teachers
}

\author{
Ibrahim Al-Hussein ${ }^{1}$, Aidah Mohammad ${ }^{1} \&$ Mona Al-Zahrani ${ }^{1}$
}

Received: September 8, 2021; Accepted: October 10, 2021; Published: October 17, 2021

\begin{abstract}
The corona (Covid-19) pandemic caused the closure of kindergarten institutions and schools around the world which forced higher authorities to shift focus towards online distance education. The impact of the pandemic was so severe that it affected almost a quarter of the people lives, public health and above all the education sectors. The present study was designed according to the Servqual Model using sample perceptions of early childhood parameters in Saudi Arabia and Jordan utilizing online questionnaires to collect the responses from 157 teachers. The quality of the online education services provided for primary school children due to Covid-19 suffered greatly as the teachers were not accustomed to the technology of distance learning. The present study recommends the need to explore the research of the high level for primary school children's study tool where teachers and parents will be able to deal with online platforms effectively. During the present unavoidable crisis, the article presents an easier and equitable platform for every child in the family.
\end{abstract}

Keywords: Covid-19, early childhood, distance education, quality of service

\section{Introduction}

The new and accelerated changes that have emerged in the light of the emerging corona pandemic around the world have led to the need to address these variables and challenges. The call is turning to alternative educational systems which enable them to live with the data and conditions of this covid-19 to maintain the continuity of the education and learning process to keep the children in an indirect relationship with their teachers/mentors and schools to support them emotionally, alleviate their fears, maintain their mental health, and reduce educational loss. Distance learning became an integral part of an educational system for all the countries around the world as it effectively contributes towards the advancement of the process of education and learning. In order to achieve high quality and competitiveness as well as the development returns of education, through the investment of modern technology and the adoption of pathways that are innovative in order to support the transition to digital learning through the distance learning system. China was the first country to develop a distance education program to cope with the covid-19 crisis. Schools entitled "School out but classes on" (Belay, 2020).

Prior to the Covid-19 pandemic, Saudi Arabia completed ambitious initiatives to improve the quality of education, including the development of teacher standards and career paths, such efforts with the ability to develop a more skilled and motivated teacher workforce (Keefe, Dellinger, Scragg, et al., 2020). When Saudi Arabia imposed the policy of social distancing to avoid the infection of corona virus, the processes of preparing electronic platforms and investing the technical resources available for the benefit of schools and learners began taking into account the situation of teachers, students, the availability of networks and internet coverage.

Although, the ministry of education has a large technical infrastructure for the implementation of distance education, users such as students, teachers and parents were not ready and trained to deal with its tools and the equipment, which help to ensure the quality education in the event of a covid-19 crisis. For example, the majority of new students did not receive enough training in the new system and some students had some problems accessing technical support, and distance education was still not suitable for practical sessions (Alshaikh, Maasher, Bayazed, et al., 2021). The results of the Bawaneh, 2021 study also indicated that science students' satisfaction with the use of distance learning and virtual classes was average. The results of these and other studies are indicators of the difficulties and problems facing the quality of distance education in early childhood during the Covid- 19 pandemic, particularly when you take into consideration the need for children in the early years to have a sensory environment and direct interaction with female teachers.

\section{The Issues and Methodology of the Study}




\subsection{Questionnaire/Survey Related to Distance Education Study}

In an effort to keep up with the developments and requirements of the times which coexist with these developments in light of the corona pandemic and improve the reality of learning and education in early childhood. The results and recommendations from literature studies (Ansari, 2020, Ramadan 2020, Al-Sawah, 2020, and Al-Qur'an, 2021) on the importance of distance learning, opportunities and challenges, researchers' desire to learn about the reality of the quality of distance education during the corona pandemic in early childhood from the point of view of teachers by exploring the answers collated from the following study questions: What is the quality of distance education service during the corona pandemic in early childhood from the point of view of female teachers, according to Servequal's five levels of (tangibles, reliability, response and assurance, safety and peace, empathy).

1. Are there any differences statistically significant at the level of significance $(.05 \geq \alpha)$ among the average responses of early childhood parameters due to study variables (type of education, number of years of experience, academic specialization, and academic qualification?)

2. Are there any differences statistically significant at the level of significance $(.05 \geq \alpha)$ among the average responses of early childhood parameters due to the context change cultural quality of distance education (Saudi Arabia- Jordan)?

\subsection{Study Objectives}

The current study sought to achieve goals:

1. Learn about the reality of the quality of distance education during the CORONA pandemic in early childhood from the point of view of female teachers.

2. Identifying differences among the average responses of early childhood teachers attributable to study variables (type of education, number of years of experience, academic specialization, and academic qualification)?

3. Identifying differences among the average responses of early childhood parameters attributable to context change cultural quality of distance education (Saudi Arabia- Jordan).

\subsection{The Importance of the Study}

The importance of the current study is as follows:

1. The current study addresses a contemporary and important issue: the quality of education under the Corona pandemic.

2. Follow-up e-education with research studies under emerging circumstances and crises.

3. The current study is expected to provide recommendations and proposals that can be used to study the development trends of early childhood distance education during crises.

4. The current study could enrich the educational library with the data and information it provides that could serve as a starting point for subsequent studies on other categories and stages.

\section{Terms and Procedural Definitions}

Quality of education: It is a strategic management process based on a set of values and draws the energy of its movement from information in which it is able to employ the talents of workers and invest their intellectual abilities at various levels of organization creatively to achieve the continuous improvement of the organization (Majid, 2014).

The researchers define the quality of education procedurally: it is one of the most important educational services that seeks to achieve the goals of achieving better results for the achievement of learners and measured in this study through the Servqual Scale in its five dimensions: (tangible objects, reliability, response and warranty, safety and safety, empathy).

Corona pandemic: Known as a viral epidemic that spreads among people in large geographical areas around the world, it affects the human respiratory system and can sometimes lead to death (Hamada, 2020).

The researchers define it procedurally as: the spread of a new infectious disease caused by a coronavirus, a description attached to a family of respiratory viruses, and more recently the term Corona is used to refer to the emerging COVID-19 pandemic, which is newly discovered, on a global scale, characterized by inability to control it, and people's weak immunity to it, which explains its rapid spread globally, causing large numbers of deaths. 
Early childhood teachers: They are teachers who have been officially appointed by the department of education to teach and care for children aged between 3-8 years.

\subsection{Theoretical Framework and Previous Studies}

The new and rapid changes that have emerged in light of the spread of the emerging Corona epidemic around the world have led to the need to face these changes and challenges. The call has become oriented towards the need to resort to alternative systems which enable learners to live with the data and conditions of this epidemic. All over the world, the system of distance education becomes demanding because of its need and vital role that contributes to the advancement of the learning process. The quality of education in raising the competitiveness rate in order to achieve the developmental benefits, integration of the education system for the investment of modern technology and adopting innovative ways to support the transition towards digital learning can be obtained by the system of distance learning.

Saudi Arabia has imposed a policy of social divergence to avoid the infection of "Covid-19" and has begun preparations for electronic platforms and the investment of the technical tools available for the benefit of schools taking into account the situation of teachers and students and the availability of networks and internet coverage.

At a time when interest in the quality of education has increased in the Arab world, both locally and globally then quality has become an objective of educational institutions as they seek to achieve in a competitive market. Additionally, the rapid and emerging developments due to the Corona pandemic is also another factor as most educational policies seek to improve quality indicators as a result of the trend towards classification and competitive rankings (Armorer \& Berger,2014).

\subsection{Distance Education and its Characteristics}

There are many ways in which a teacher is effective in e-learning and distance education. Distance education is defined as "a method of teaching and learning using modern communication mechanisms primarily to communicate information to the learner and to constant communication between students and teachers (Alqharib, 2010).

Ashi (2018:106) defines it as a method that provides the findings for the learning process in its various forms using electronic displays in traditional classrooms and ends with the construction of virtual schools.

From the above, it can be said that distance education is the process of transferring learning to the learner in his or her place of residence or work instead of moving the learner to the educational institution itself, where this type of education provides appropriate social spacing under emergency conditions caused by the corona virus.

\subsection{Features of Distance Education}

Distance education is characterized by the following (Ramadan, 2020):

1. Providing the distance between the learner and the teacher, which frees them from the constraints of space and time compared to the usual education systems that require confrontation between them.

2. A two-way connection between the educational institution and the learner to help him benefit and engage in dialogue with the students.

3. To integrate the classroom systems and the approved hours as they achieve the advantages of the two systems and avoid the greatest negatives.

The role of distance education in solving the problems of the teaching and learning process during the CORONA pandemic

After quarantine imposed, a new reality on all fields including education, and after distance education became the alternative, the information revolution imposed on learners self-learning skills to make them able to make decisions, take responsibility and make self-effort to activate information programs and applications and interact with remote education platforms, The Ministries of Education have also designed special educational platforms through which courses can be taught and educated interact with learners, and these platforms have solved the problems that emerged during the CORONA pandemic, thus contributing to improved quality indicators through efforts to improve education policies and procedures (Al-Musa, 2018).

Saudi Arabia has followed this interest and acceleration through the evaluation of learning outcomes for educational institutions, and one of the most important aspects of this interest was the follow-up of the Education Calendar Authority, which was established in 2016 to work during the corona pandemic and to ensure that the quality of education based on statistics and indicators capable of diagnosing reality (Al-Musa, 2018) is keen to assess the quality of education based on statistics and indicators capable of diagnosing reality (Al-Musa, 2018). 


\subsection{Related Research Studies}

For the purposes of achieving the objectives of the current study, previous studies will be reviewed from the oldest to the latest as follows:

Al-Rashid Study (2018) aimed at identifying the trends of kindergarten teachers towards digital learning and the degree of possessing their digital learning skills, and reached the sample of study (120) teachers of kindergartens in Riyadh. The study used resolution as a data collection tool, and the results indicated positive trends towards digital learning in the study sample, and the results indicated that the digital learning skills of the study sample parameters were moderate.

Burdina, Krapotkina \&Nasyrova(2019) study aimed at investigating the impact of distance education in primary school and kindergarten classrooms and consisted of a sample of (430) students from all over the Republic of Tatar Stan from the Balkans. The results showed that the distance education curriculum in primary schools requires an amendment because students need teachers to guide them and help them increase their efficiency in academic performance.

Foti (2020) study aimed to explore perceptions, possibilities and limitations related to the implementation of distance education in kindergartens during the Corona pandemic and used the study as a data collection tool, and the results indicated that teachers responded to the application of distance education in order to maintain communication with their students, and to respond to help the Greek family educate their children.

Ansari(2020) study the goal of luxury on a proposed vision of the roles of the teacher in the face of challenges that hinder the quality of e-education in educational institutions, the study adopted the descriptive curriculum survey in addition to the analytical descriptive approach to discuss the questions of the study. The study was formed from a sample of faculty members in a group of (20) faculty members from different disciplines. The results of the study pointed to the need to spread cultural awareness of the concept of the quality of e-learning and link it to the subject of scientific development of teacher preparation programs and promote the concept of the quality of e-education in educational institutions.

Study (Hamada, 2020), which sought to identify the trends of teachers in the Beni Kanana Brigade in Jordan towards the effectiveness of the Noor Space platform used during the Corona pandemic, used the survey as a data collection tool, (932) Teachers selected in the random class method, and the results indicated that the trends of school teachers sample study towards the effectiveness of the platform (Noor Space) came largely and the presence of statistically significant differences due to the variable years of experience and the absence of statistically significant differences attributable to the variable of scientific qualification.

Quran (2021) study aimed to identify the reality of e-education in light of the Corona pandemic among Riyadh children from the point of view of teachers in the directorate of education in Irbid- Jordan. To achieve the objectives of the study used the questionnaire as a tool to collect data from a sample of (211) teachers selected in a simple random way, and the results showed that estimates of the reality of e-education in light of the Corona pandemic in Riyadh children from the point of view of teachers in the Directorate of Education in Irbid ProvinceJordan came to an average degree. The results also indicated differences due to the change in the type of kindergarten and in favor of special kindergartens and the existence of differences due to the variable of scientific qualification and in favor of graduate studies and the existence of differences due to the variable years of experience and in favor of estimates of years of experience (more than 10 years).

Study (Madini, 2021) which aimed to identify the most challenges faced by kindergarten teachers in distance education in light of the spread of the Corona pandemic using the descriptive curriculum and questionnaire as a tool to collect data from a sample of government and civil kindergarten teachers in Jeddah and the results showed that the most challenges faced by the teacher's sample study are the challenges of dealing with techniques. The results also showed differences due to the type of educational institution and to the benefit of public schools and differences attributable to years of experience and to years of experience (10 years and older).

O'Keefe et al., (2020) aimed at understanding the state of kindergarten education through the end of online secondary education before and after COVID in Saudi Arabia, based on the academic period from $9^{\text {th }}$ March to $14^{\text {th }}$ May 2020, to identify opportunities for improvement while identifying areas of excellence that can be highlighted against the online learning quality assessment framework from kindergarten to grade 12, including leadership dimensions. Curriculum design, planning, online education, learning, evaluation, technology, student support, training support, evaluation and continuous improvement has appeared throughout the study. Prior to COVID, online education supporting K-12 in Saudi Arabia was largely complementary to traditional education, providing an increase in infrastructure and capabilities as a priority and part of Vision 2030. 
The current study benefited from previous work by preparing the tool and discussing and interpreting the results as well as being taken by early childhood teachers in both categories preschool teachers and. $1^{\text {st }}$ to $3^{\text {rd }}$ grade primary teachers. In addition to the current study similar to some studies in the selection of variables such as study (Medina, 2021 and Pumpkins, 2021).

\section{The Method and Procedures of the Study}

\subsection{Study Approach}

To achieve the objectives of the study, the researchers adopted the descriptive survey method using questionnaire, as the study aims to monitor the perceptions of female teachers about the phenomenon that has emerged on early childhood education, namely distance education, because this type of research describes what is a reality and requires the registration, analysis and interpretation of the status quo (Best, 2018).

\subsection{Sample of the Study}

The current study sample was made up of (157) early childhood parameters, table (1) showing the distribution of the study sample according to the study variables.

Table 1. shows the distribution of the study sample by study variables

\begin{tabular}{lll}
\hline Criterion & Value Label & Number \\
\hline Education & Public schools & 75 \\
& Private schools & 82 \\
Experience & $1-3$ years & 38 \\
& 4-6 years & 35 \\
& More than 6 years & 84 \\
\multirow{2}{*}{ Specialization } & kindergarten & 109 \\
& Other specialties & 48 \\
\multirow{2}{*}{ Qualification } & Bachelor & 128 \\
& Postgraduate & 29 \\
\multirow{2}{*}{ Country } & Saudi Arabia & 103 \\
& Jordan & 54 \\
\hline
\end{tabular}

\subsection{Study Tool}

To achieve the objectives of the study, the researchers developed the study tool by reference to the Servequal measure of parameter perceptions, which were formed from (31) paragraphs distributed across the five areas of the scale: (tangible objects- reliability- response and assurance- peaceful and safety -empathy) according to the triangular LIKERT staging (OK, neutral,non-agree). The data was collected through a three-week online questionnaire, particularly sites and social media pages related to teachers.

\subsection{Authenticity of the Tool}

\subsubsection{Structural Credibility}

The study tool was applied to a reconnaissance sample from outside the study sample consisting of (25) parameters from outside the study sample and the Pearson correlation factor was calculated between the paragraph and the overall degree of the area to which it belonged and between the paragraph, the axis, the overall degree and table (2) indicating this: 
Table 2. Pearson's correlation factor between the paragraph and the overall degree of the area to which it belongs and the paragraph, field and overall degree

\begin{tabular}{|c|c|c|c|c|c|}
\hline & $\stackrel{\bar{\Xi}}{\stackrel{\Xi}{\circlearrowright}}$ & 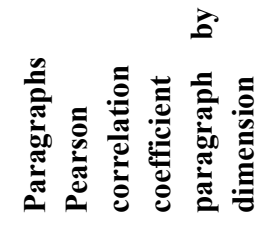 & : & 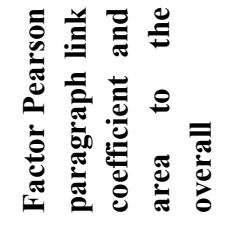 & 总 \\
\hline & The first area: tangible things & & & $.962^{* *}$ & .000 \\
\hline 1 & $\begin{array}{l}\text { Possess the minimum knowledge, technical skills and } \\
\text { competencies required for distance education }\end{array}$ & $.676^{* *}$ & .000 & $.570^{* *}$ & .003 \\
\hline 2 & $\begin{array}{l}\text { The distance education system provides me with access } \\
\text { to all the programs that serve the distance education } \\
\text { process }\end{array}$ & $.870^{* *}$ & .000 & $.848^{* *}$ & .000 \\
\hline 3 & $\begin{array}{l}\text { The distance education system provides me with easy } \\
\text { techniques and ways to obtain them }\end{array}$ & $.911^{* *}$ & .000 & $.883^{* *}$ & .000 \\
\hline 4 & $\begin{array}{l}\text { The distance education system allows the presentation } \\
\text { of electronic content in multiple audio-visual ways }\end{array}$ & $.818^{* *}$ & .000 & $.876^{* *}$ & .000 \\
\hline 5 & $\begin{array}{l}\text { There are important guidelines for parents and students } \\
\text { for the success of distance learning }\end{array}$ & $.926^{* *}$ & .000 & $.915^{* *}$ & .000 \\
\hline 6 & $\begin{array}{l}\text { The distance education system provides an electronic } \\
\text { alert feature to constantly alert learners }\end{array}$ & $.908^{* *}$ & .000 & $.923^{* *}$ & .000 \\
\hline 7 & $\begin{array}{l}\text { The technical infrastructure of the Internet is available } \\
\text { to help all students for easy access to the distance } \\
\text { education service }\end{array}$ & $.848^{* *}$ & .000 & $.832^{* *}$ & .000 \\
\hline 8 & $\begin{array}{l}\text { Technical support service is available for students, } \\
\text { parents and teachers during the distance education } \\
\text { process }\end{array}$ & $.835^{* *}$ & .000 & $.803^{* *}$ & .000 \\
\hline 9 & I use the e-learning system on my smartphone. & $.818^{* *}$ & .000 & $.730^{* *}$ & .000 \\
\hline 10 & $\begin{array}{l}\text { Distance education provides teachers with opportunities } \\
\text { to innovate in methods and technologies that deepen } \\
\text { student learning }\end{array}$ & $.846^{* *}$ & .000 & $.770^{* *}$ & .000 \\
\hline & $\begin{array}{l}\text { The second area: reliability (measuring the ability of } \\
\text { the distance education service to meet the needs and } \\
\text { aspirations of the beneficiaries: students, parents, } \\
\text { teachers) }\end{array}$ & & & $.960^{* *}$ & .000 \\
\hline 11 & $\begin{array}{l}\text { Distance education is suitable for early childhood age } \\
\text { group (3-6) }\end{array}$ & $.866^{* *}$ & .000 & $.796^{* *}$ & .000 \\
\hline 12 & $\begin{array}{l}\text { Provides distance education Use appropriate } \\
\text { applications to teach children with learning difficulties } \\
\text { in early childhood }\end{array}$ & $.833^{* *}$ & .000 & $.822^{* *}$ & .000 \\
\hline 13 & $\begin{array}{l}\text { Provides distance education Use distance learning } \\
\text { applications efficiently to help the learner achieve } \\
\text { global learning standards }\end{array}$ & $.870^{* *}$ & .000 & $.791^{* *}$ & .000 \\
\hline 14 & $\begin{array}{l}\text { In distance education, we use various tools to assess } \\
\text { student learning to ensure the quality of assessment of } \\
\text { their learning }\end{array}$ & $.946^{* *}$ & .000 & $.941^{* *}$ & .000 \\
\hline 15 & $\begin{array}{l}\text { Distance education provides opportunities to follow the } \\
\text { interaction of learners to obtain data and information }\end{array}$ & $.857^{* *}$ & .000 & $.839^{* *}$ & .000 \\
\hline
\end{tabular}




\begin{tabular}{|c|c|c|c|c|c|}
\hline 16 & $\begin{array}{l}\text { Distance education provides innovation opportunities } \\
\text { for teachers to provide students with specific learning } \\
\text { outcomes }\end{array}$ & $.779^{* *}$ & .000 & $.757^{* *}$ & .000 \\
\hline & $\begin{array}{l}\text { The third area: Response and Assurance (measuring } \\
\text { efficiency, tact, credibility and speed of response in } \\
\text { providing distance education service to students, } \\
\text { parents and teacher }\end{array}$ & & & $.839^{* *}$ & .000 \\
\hline 17 & $\begin{array}{l}\text { Distance education provides opportunities to employ } \\
\text { methods for measuring learners' interaction and } \\
\text { engagement during the educational presentation }\end{array}$ & $.767^{* *}$ & .000 & $.833^{* *}$ & .000 \\
\hline 18 & $\begin{array}{l}\text { In distance education, we use multiple tools to assess the } \\
\text { expected learning outcomes (including: pre-assessment } \\
\text { tools - formative - final) }\end{array}$ & $.855^{* *}$ & .000 & $.657^{* *}$ & .000 \\
\hline 19 & $\begin{array}{l}\text { In distance education, we use tools to assess active } \\
\text { learning during lessons }\end{array}$ & $.881^{* *}$ & .000 & $.664^{* *}$ & .001 \\
\hline 20 & $\begin{array}{l}\text { We use procedures to ensure the integrity of online } \\
\text { assessments Online }\end{array}$ & $.833^{* *}$ & .000 & $.608^{* *}$ & .000 \\
\hline \multirow[t]{2}{*}{21} & $\begin{array}{l}\text { Assessments of early childhood learners accurately } \\
\text { measure expected learning outcomes }\end{array}$ & $.408^{*}$ & .043 & $.767^{* *}$ & .000 \\
\hline & $\begin{array}{l}\text { Fourth Domain: Safety and security (measuring the } \\
\text { extent to which the distance education service } \\
\text { provider cares about teachers and administrators } \\
\text { and the extent to which they are familiar with their } \\
\text { jobs and their interaction with learners and } \\
\text { parents). }\end{array}$ & & & $.915^{* *}$ & .000 \\
\hline 22 & $\begin{array}{l}\text { We receive adequate training on the minimum } \\
\text { knowledge, technical skills and competencies required } \\
\text { to use distance education }\end{array}$ & $.870^{* *}$ & .000 & $.772^{* *}$ & .000 \\
\hline 23 & $\begin{array}{l}\text { The distance education service provides training } \\
\text { opportunities to take care of the psychological aspects } \\
\text { of learners }\end{array}$ & $.651^{* *}$ & .000 & $.493^{*}$ & .012 \\
\hline 24 & $\begin{array}{l}\text { Incentives and rewards are available to encourage and } \\
\text { appreciate female teachers for the success of distance } \\
\text { education }\end{array}$ & $.891^{* *}$ & .000 & $.919^{* *}$ & .000 \\
\hline \multirow[t]{2}{*}{25} & $\begin{array}{l}\text { Practical guides are available to illustrate distance } \\
\text { education quality assurance procedures }\end{array}$ & $.887^{* *}$ & .000 & $.936^{* *}$ & .000 \\
\hline & $\begin{array}{l}\text { Fifth Domain: The Fifth Dimension: Empathy } \\
\text { (measuring how service is delivered, communication, } \\
\text { and understanding of beneficiaries) }\end{array}$ & & & $.942^{* *}$ & .000 \\
\hline 26 & $\begin{array}{l}\text { Distance education provides applications/electronic } \\
\text { platforms suitable for teaching students with learning } \\
\text { disabilities }\end{array}$ & $.916^{* *}$ & .000 & $.919^{* *}$ & .000 \\
\hline 27 & $\begin{array}{l}\text { Distance education provides content in different designs } \\
\text { in terms of color, shape and size, which reduces effort }\end{array}$ & $.939^{* *}$ & .000 & $.946^{* *}$ & .000 \\
\hline 28 & $\begin{array}{l}\text { Distance education provides electronic content in } \\
\text { various forms (texts, presentations, audio materials.) }\end{array}$ & $.928^{* *}$ & .000 & $.850^{* *}$ & .000 \\
\hline 29 & $\begin{array}{l}\text { Distance education provides feedback techniques to } \\
\text { each learner on the tasks performed on an ongoing basis }\end{array}$ & $.898^{* *}$ & .000 & $.804^{* *}$ & .000 \\
\hline 30 & Distance education provides self-assessment methods & $.932^{* *}$ & .000 & $.837^{* *}$ & .000 \\
\hline
\end{tabular}




\begin{tabular}{|l|l|l|l|l|l|}
\hline & for learners to check their progress & & & \\
\hline 31 & $\begin{array}{l}\text { The distance learning system provides a mechanism to } \\
\text { measure the degree of satisfaction of teachers, students } \\
\text { and parents with the distance education service }\end{array}$ & $.919^{* *}$ & .000 & $.854^{* *}$ & .000 \\
\hline
\end{tabular}

** Function at the significance level $(0.01), *$ Function at $(0.05)$

It is clear from Table (2) that the values of Pearson's correlation coefficients between the paragraphs of the questionnaire and the total degree of the domain to which it belongs are statistically significant at the significance level (0.01) or (0.05), and this indicates that all the questionnaire's expressions have a degree of sincerity, which indicates that the validity of the tool to measure what prepared for him.

\subsubsection{Stability Coefficient of the Study}

To calculate the values of the scale stability coefficient, the researchers applied the questionnaire to the exploratory sample consisting of (25) and the values of the reliability coefficient were calculated using Cronbach's alpha coefficient. Cronbach's Alpha and Table (3) show the stability coefficients for the fields and for the overall instrument score:

Table 3. Cronbach's alpha stability coefficients for the fields

\begin{tabular}{ll}
\hline \multicolumn{1}{c}{ The field } & Cronbach's Alpha stability coefficient \\
\hline The first dimension: Tangible things & 0.95 \\
The second dimension: Reliability & 0.92 \\
The third dimension: Response and guarantee & 0.81 \\
Fourth dimension: Safety and security & 0.89 \\
The fifth dimension: Empathy & 0.94 \\
\hline Total marks & $\mathbf{0 . 9 7}$ \\
\hline
\end{tabular}

It is clear from the table that the stability coefficient of the total degree reached (0.97) and the stability coefficients on the domains ranged $(0.81-0.95)$, which indicates that the tool has high stability.

\subsection{Statistical Methods}

To answer the study questions, the researchers used a number of statistical methods to apply them in the SPSS statistical analysis program version (23) where the arithmetic means, standard deviations were extracted to answer the first and third question, analysis of variance was used to answer the second and fourth questions, and the Pearson correlation coefficient. To answer the fifth question, the results of the arithmetic mean value were interpreted in a scale according to the triple scale used in the current study:

a) The range is calculated, $3-1=2$.

b) The length of the category is calculated by dividing the range by the number of categories according to the category length $2 / 3=66,0$, from 1 to $1.66---$ few, from 1.67 - less than 2.33 medium, from $2.34-3.00$ large.

\subsection{Study Results and Discussion}

The results of the first question: What is the quality level of the distance education service during the Corona pandemic in early childhood from the point of view of the teachers, according to the five levels of the Servequal scale (tangible things - reliability - response and guarantee - safety and safety - empathy)?

Table 4. Arithmetic averages and standard deviations of the quality level of distance education service during the Corona pandemic in early childhood from the point of view of the teachers

\begin{tabular}{|l|l|l|l|l|}
\hline & Dimension - Vertebrae & $\begin{array}{l}\text { Arithmetic } \\
\text { averages }\end{array}$ & $\begin{array}{l}\text { Averages } \\
\text { Standard }\end{array}$ & Level \\
\hline & The first area: Tangible things & 2.46 & .477 & Big \\
\hline 1 & $\begin{array}{l}\text { Possess the minimum knowledge, technical skills and } \\
\text { competencies required for distance education }\end{array}$ & 2.54 & .730 & Big \\
\hline
\end{tabular}




\begin{tabular}{|c|c|c|c|c|}
\hline 2 & $\begin{array}{l}\text { The distance education system provides me with access to all } \\
\text { the programs that serve the distance education process }\end{array}$ & 2.47 & .773 & Big \\
\hline 3 & $\begin{array}{l}\text { The distance education system provides me with easy } \\
\text { techniques and ways to obtain them }\end{array}$ & 2.57 & .672 & Big \\
\hline 4 & $\begin{array}{l}\text { The distance education system allows the presentation of } \\
\text { electronic content in multiple audio-visual ways }\end{array}$ & 2.76 & .533 & Big \\
\hline 5 & $\begin{array}{l}\text { There are important guidelines for parents and students for the } \\
\text { success of distance learning }\end{array}$ & 2.64 & .690 & Big \\
\hline 6 & $\begin{array}{l}\text { The distance education system provides an electronic alert } \\
\text { feature to constantly alert learners }\end{array}$ & 2.28 & .783 & Medium \\
\hline 7 & $\begin{array}{l}\text { The technical infrastructure of the Internet is available to help } \\
\text { all students for easy access to the distance education service }\end{array}$ & 2.15 & .823 & Medium \\
\hline 8 & $\begin{array}{l}\text { Technical support service is available for students, parents and } \\
\text { teachers during the distance education process }\end{array}$ & 2.16 & .844 & Medium \\
\hline 9 & I use the e-learning system on my smartphone. & 2.42 & .848 & Big \\
\hline 10 & $\begin{array}{l}\text { Distance education provides teachers with innovation } \\
\text { opportunities in instruction and techniques that deepen student } \\
\text { learning }\end{array}$ & 2.61 & .677 & Big \\
\hline & $\begin{array}{l}\text { The second area: } \\
\text { Reliability (measuring the ability of the distance education } \\
\text { service to meet the needs and aspirations of the } \\
\text { beneficiaries: students, parents, teachers). }\end{array}$ & 2.15 & .681 & Medium \\
\hline 11 & $\begin{array}{l}\text { Distance education is suitable for early childhood age group (3- } \\
6 \text { ) }\end{array}$ & 1.82 & .854 & Medium \\
\hline 12 & $\begin{array}{l}\text { Provides distance education use appropriate applications to } \\
\text { teach children with learning disabilities in early childhood }\end{array}$ & 1.85 & .833 & Medium \\
\hline 13 & $\begin{array}{l}\text { Provides distance education use distance learning applications } \\
\text { efficiently to help the learner achieve global learning standards }\end{array}$ & 2.19 & .802 & Medium \\
\hline 14 & $\begin{array}{l}\text { In distance education, we use various tools to assess student } \\
\text { learning to ensure the quality of assessment of their learning }\end{array}$ & 2.34 & .852 & Big \\
\hline 15 & $\begin{array}{l}\text { Distance education provides opportunities to follow the } \\
\text { interaction of learners to obtain data and information }\end{array}$ & 2.33 & .812 & Medium \\
\hline 16 & $\begin{array}{l}\text { Distance education provides innovation opportunities for } \\
\text { teachers to provide students with specific learning outcomes }\end{array}$ & 2.39 & .806 & Big \\
\hline & $\begin{array}{l}\text { The third area: Response and Assurance (measuring } \\
\text { efficiency, tact, credibility and speed of response in } \\
\text { providing distance education service to students, parents } \\
\text { and teachers }\end{array}$ & 2.32 & .637 & Medium \\
\hline 17 & $\begin{array}{l}\text { Distance education provides opportunities to employ methods } \\
\text { for measuring learners' interaction and engagement during the } \\
\text { educational presentation }\end{array}$ & 2.36 & .776 & Big \\
\hline 18 & $\begin{array}{l}\text { In distance education, we use multiple tools to assess the } \\
\text { expected learning outcomes (including: pre-assessment tools - } \\
\text { formative - final) }\end{array}$ & 2.37 & .736 & Big \\
\hline 19 & $\begin{array}{l}\text { In distance education, we use tools to assess active learning } \\
\text { during lessons }\end{array}$ & 2.55 & .711 & Big \\
\hline 20 & We use procedures to ensure the integrity of online assessments & 2.36 & .769 & Big \\
\hline 21 & $\begin{array}{l}\text { Online assessments of early childhood learners accurately } \\
\text { measure expected learning outcomes }\end{array}$ & 1.98 & .858 & Medium \\
\hline & $\begin{array}{l}\text { Fourth Domain: } \\
\text { Safety and security (measuring the extent to which the } \\
\text { distance education service provider cares about teachers } \\
\text { and administrators and the extent to which they are familiar } \\
\text { with their jobs and their interaction with learners and } \\
\text { parents). }\end{array}$ & 2.10 & .684 & Medium \\
\hline
\end{tabular}




\begin{tabular}{|l|l|l|l|l|}
\hline 22 & $\begin{array}{l}\text { We receive adequate training on the minimum knowledge, } \\
\text { technical skills and competencies required to use distance } \\
\text { education }\end{array}$ & 2.20 & .828 & Medium \\
\hline 23 & $\begin{array}{l}\text { The distance education service provides training opportunities } \\
\text { to take care of the psychological aspects of learners }\end{array}$ & 2.08 & .844 & Medium \\
\hline 24 & $\begin{array}{l}\text { Incentives and rewards are available encourage and } \\
\text { appreciate female teachers for the success of distance education }\end{array}$ & 2.03 & .877 & Medium \\
\hline 25 & $\begin{array}{l}\text { Practical guides are available to illustrate distance education } \\
\text { quality assurance procedures }\end{array}$ & 2.20 & .804 & Medium \\
\hline $\begin{array}{l}\text { Fifth Domain: } \\
\text { Empathy (measuring how service is delivered, } \\
\text { communication, and understanding of beneficiaries) }\end{array}$ & 2.46 & .600 & Medium \\
\hline 26 & $\begin{array}{l}\text { Distance education provides applications/electronic platforms } \\
\text { suitable for teaching students with learning disabilities }\end{array}$ & 2.46 & .747 & Big \\
\hline 27 & $\begin{array}{l}\text { Distance education provides content in different designs in } \\
\text { terms of color, shape and size, which reduces effort }\end{array}$ & 2.68 & .621 & Big \\
\hline 28 & $\begin{array}{l}\text { Distance education provides electronic content in various forms } \\
\text { (texts, presentations, audio materials..) }\end{array}$ & 2.47 & .730 & Big \\
\hline 29 & $\begin{array}{l}\text { Distance education provides feedback techniques to each } \\
\text { learner on the tasks performed on an ongoing basis }\end{array}$ & 2.41 & .760 & Big \\
\hline 30 & $\begin{array}{l}\text { Distance education provides self-assessment methods for } \\
\text { learners to check their progress }\end{array}$ & 2.26 & .818 & Big \\
\hline 31 & $\begin{array}{l}\text { The distance learning system provides a mechanism to measure } \\
\text { the degree of satisfaction of teachers, students and parents with } \\
\text { the distance education service }\end{array}$ & 2.30 & .747 \\
\hline Total marks & 2.32 & .522 & Medium \\
\hline
\end{tabular}

It is clear from Table (4), that the quality level of the distance education service during the Corona pandemic in early childhood from the point of view of the female teachers was with an arithmetic mean (2.32) and a standard deviation (0.552), with a medium degree, and the researchers attribute this to the fact that the transition to distance education was surprising. For learners, teachers, parents, and the needs training and rehabilitation to deal with it, and the first field: tangible things got an arithmetic mean (2.46) and a standard deviation (0.477) to a large degree, and this may be attributed to the early childhood teachers possessing the minimum knowledge and technical skills and competencies required for distance education, and the distance learning system provides female teachers with access to all programs that serve the distance education process, and the second field of reliability obtained an arithmetic average. Arithmetic (2.15) and standard deviation (0.681) with a medium degree, and the third field: response and guarantee got an arithmetic mean (2.32) and standard deviation (0.637) and a medium degree, and the fourth field: safety and security got a mean (2.10) and standard deviation (0.648) and a medium degree. The fifth field of empathy also got an arithmetic mean (2.46) and a standard deviation (0.600) to a large degree, and the researchers attribute this to the limitation of directing observations to students via the Internet, in addition to the loss of direct communication with the child.

The results of the second question: Are there statistically significant differences at the level of significance $(\alpha \geq .05)$ between the average responses of early childhood teachers due to study variables (type of education, number of years of experience, academic specialization, academic qualification, cultural context). In order to answer this question, the arithmetic means and standard deviations of the responses of early childhood teachers were extracted due to the study variables (type of education, number of years of experience, academic specialization, qualification and Table (5) shows that:

Table 5. Means and standard deviations of early childhood teachers' responses due to study variables (type of education, number of years of experience, academic specialization qualification).

\begin{tabular}{|l|l|l|l|l|l|l|l|}
\hline Variable & Category & 1st field & $\begin{array}{l}\mathbf{2}^{\text {nd }} \\
\text { field }\end{array}$ & $3^{\text {rd }}$ field & $\begin{array}{l}\mathbf{4}^{\text {th }} \\
\text { field }\end{array}$ & 5th field & $\begin{array}{l}\text { Total } \\
\text { marks }\end{array}$ \\
\hline
\end{tabular}




\begin{tabular}{|l|l|l|l|l|l|l|l|l|l|l|l|l|l|}
\hline & & $\mathbf{M}$ & $\mathbf{A}$ & $\mathbf{M}$ & $\mathbf{A}$ & $\mathbf{M}$ & $\mathbf{A}$ & $\mathbf{M}$ & $\mathbf{A}$ & $\mathbf{M}$ & $\mathbf{A}$ & $\mathbf{M}$ & $\mathbf{A}$ \\
\hline \multirow{2}{*}{$\begin{array}{l}\text { Education } \\
\text { type }\end{array}$} & Government & 2.41 & .487 & 2.15 & .655 & 2.28 & .649 & 1.95 & .679 & 2.42 & .627 & 2.27 & .514 \\
\cline { 2 - 12 } & Private & 2.50 & .466 & 2.15 & .707 & 2.37 & .628 & 2.23 & .665 & 2.49 & .576 & 2.37 & .529 \\
\hline \multirow{2}{*}{ Specialization } & Kindergarten & 2.38 & .479 & 2.05 & .674 & 2.22 & .658 & 1.92 & .670 & 2.36 & .632 & 2.21 & .519 \\
\cline { 2 - 12 } & Other & 2.64 & .425 & 2.38 & .645 & 2.57 & .515 & 2.50 & .527 & 2.68 & .450 & 2.56 & .447 \\
\hline \multirow{2}{*}{ Experience } & $\mathbf{( 1 - 3 ) \text { years }}$ & 2.48 & .576 & 2.18 & .816 & 2.50 & .642 & 2.27 & .746 & 2.49 & .637 & 2.39 & .602 \\
\cline { 2 - 11 } & $\mathbf{( 4 - 6 ) \text { years }}$ & 2.40 & .499 & 2.09 & .674 & 2.21 & .664 & 1.91 & .646 & 2.42 & .581 & 2.23 & .538 \\
\cline { 2 - 12 } & $\begin{array}{l}\text { More than (6) } \\
\text { years }\end{array}$ & 2.48 & .419 & 2.17 & .621 & 2.30 & .615 & 2.09 & .657 & 2.46 & .597 & 2.32 & .476 \\
\hline \multirow{2}{*}{ Qualification } & (BA) Bachelor & 2.45 & .499 & 2.14 & .707 & 2.33 & .641 & 2.09 & .698 & 2.44 & .624 & 2.31 & .545 \\
\cline { 2 - 11 } & Postgraduate & 2.52 & .364 & 2.22 & .553 & 2.30 & .634 & 2.13 & .629 & 2.56 & .476 & 2.37 & .412 \\
\hline
\end{tabular}

Table (5) shows a difference in the arithmetic averages of the responses of early childhood teachers due to the study variables (type of education, number of years of experience, academic specialization and qualification).

Table 6. Analysis of variance: for early childhood teacher's responses due to study variables (type of education, number of years of experience, academic specialization and qualification).

\begin{tabular}{|c|c|c|c|c|c|c|}
\hline Source & Field & $\begin{array}{l}\text { Sum of } \\
\text { squares }\end{array}$ & $\begin{array}{l}\text { Degrees of } \\
\text { freedom }\end{array}$ & $\begin{array}{l}\text { Average of } \\
\text { squares }\end{array}$ & $\mathbf{P}$ & $\begin{array}{l}\text { Statistical } \\
\text { significance }\end{array}$ \\
\hline \multirow[t]{6}{*}{$\begin{array}{l}\text { Type of the } \\
\text { Education }\end{array}$} & $\begin{array}{l}\text { The first dimension: } \\
\text { tangible things }\end{array}$ & .008 & 1 & .008 & .035 & .851 \\
\hline & $\begin{array}{lr}\text { The } & \text { second } \\
\text { dimension: reliability }\end{array}$ & .427 & 1 & .427 & .951 & .331 \\
\hline & $\begin{array}{l}\text { The third dimension: } \\
\text { response and } \\
\text { guarantee }\end{array}$ & .049 & 1 & .049 & .127 & .722 \\
\hline & $\begin{array}{l}\text { Fourth dimension: } \\
\text { Safety and Security }\end{array}$ & .414 & 1 & .414 & 1.048 & .308 \\
\hline & $\begin{array}{l}\text { The fifth dimension: } \\
\text { empathy }\end{array}$ & .024 & 1 & .024 & .069 & .793 \\
\hline & Total marks & .003 & 1 & .003 & .012 & .913 \\
\hline \multirow[t]{6}{*}{ Experience } & $\begin{array}{l}\text { The first dimension: } \\
\text { tangible things }\end{array}$ & .147 & 2 & .073 & .336 & .715 \\
\hline & $\begin{array}{lr}\text { The } & \text { second } \\
\text { dimension: reliability }\end{array}$ & .142 & 2 & .071 & .158 & .854 \\
\hline & $\begin{array}{l}\text { The third dimension: } \\
\text { response and } \\
\text { guarantee }\end{array}$ & 1.018 & 2 & .509 & 1.322 & .270 \\
\hline & $\begin{array}{l}\text { Fourth dimension: } \\
\text { Safety and Security }\end{array}$ & 1.271 & 2 & .636 & 1.610 & .203 \\
\hline & $\begin{array}{l}\text { The fifth dimension: } \\
\text { empathy }\end{array}$ & .045 & 2 & .022 & .065 & .937 \\
\hline & Total marks & .252 & 2 & .126 & .500 & .608 \\
\hline \multirow[t]{5}{*}{ Specialization } & $\begin{array}{l}\text { The first dimension: } \\
\text { tangible things }\end{array}$ & 1.858 & 1 & 1.858 & 8.498 & .004 \\
\hline & $\begin{array}{lr}\text { The } & \text { second } \\
\text { dimension: reliability }\end{array}$ & 4.077 & 1 & 4.077 & 9.080 & .003 \\
\hline & $\begin{array}{l}\text { The third dimension: } \\
\text { response and } \\
\text { guarantee }\end{array}$ & 3.357 & 1 & 3.357 & 8.717 & .004 \\
\hline & $\begin{array}{l}\text { Fourth dimension: } \\
\text { Safety and Security }\end{array}$ & 8.183 & 1 & 8.183 & 20.721 & .000 \\
\hline & The fifth dimension: & 3.282 & 1 & 3.282 & 9.497 & .002 \\
\hline
\end{tabular}




\begin{tabular}{|c|c|c|c|c|c|c|}
\hline & empathy & & & & & \\
\hline & Total marks & 3.533 & 1 & 3.533 & 14.014 & .000 \\
\hline \multirow[t]{6}{*}{ Qualification } & $\begin{array}{l}\text { The first dimension: } \\
\text { tangible things }\end{array}$ & .140 & 1 & .140 & .640 & .425 \\
\hline & $\begin{array}{lr}\text { The } & \text { second } \\
\text { dimension: reliability }\end{array}$ & .213 & 1 & .213 & .475 & .492 \\
\hline & $\begin{array}{l}\text { The third dimension: } \\
\text { response and } \\
\text { guarantee }\end{array}$ & .004 & 1 & .004 & .011 & .917 \\
\hline & $\begin{array}{l}\text { Fourth Dimension: } \\
\text { Safety and Security }\end{array}$ & .214 & 1 & .214 & .543 & .463 \\
\hline & $\begin{array}{l}\text { The fifth dimension: } \\
\text { empathy }\end{array}$ & .416 & 1 & .416 & 1.203 & .274 \\
\hline & Total marks & .159 & 1 & .159 & .632 & .428 \\
\hline \multirow[t]{6}{*}{ Errors } & $\begin{array}{l}\text { The first dimension: } \\
\text { tangible things }\end{array}$ & 33.009 & 151 & .219 & & \\
\hline & $\begin{array}{lr}\text { The } & \text { second } \\
\text { dimension: reliability }\end{array}$ & 67.799 & 151 & .449 & & \\
\hline & $\begin{array}{l}\text { The third dimension: } \\
\text { response and } \\
\text { guarantee }\end{array}$ & 58.158 & 151 & .385 & & \\
\hline & $\begin{array}{l}\text { Fourth Dimension: } \\
\text { Safety and Security }\end{array}$ & 59.633 & 151 & .395 & & \\
\hline & $\begin{array}{l}\text { The fifth dimension: } \\
\text { empathy }\end{array}$ & 52.190 & 151 & .346 & & \\
\hline & Total marks & 38.067 & 151 & .252 & & \\
\hline \multirow[t]{6}{*}{ Overall } & $\begin{array}{l}\text { The first dimension: } \\
\text { tangible things }\end{array}$ & 984.970 & 157 & & & \\
\hline & $\begin{array}{l}\text { The second } \\
\text { dimension: } \\
\text { dimensionality }\end{array}$ & 799.250 & 157 & & & \\
\hline & $\begin{array}{l}\text { The third dimension: } \\
\text { response and } \\
\text { guarantee }\end{array}$ & 911.960 & 157 & & & \\
\hline & $\begin{array}{l}\text { Fourth Dimension: } \\
\text { Safety and Security }\end{array}$ & 762.440 & 157 & & & \\
\hline & $\begin{array}{l}\text { The fifth dimension: } \\
\text { empathy }\end{array}$ & 1005.200 & 157 & & & \\
\hline & Total marks & 887.063 & 157 & & & \\
\hline
\end{tabular}

\subsection{Education Type Variable}

Table (6) shows that there are no statistically significant differences in the responses of early childhood teachers due to the type of education in the fields and in the total degree. The researchers attribute this to the fact that managing the distance education system in public and private schools is an advanced educational experience that contributes to providing teachers, students and parents with the means of more effective and productive for collaboration, communication and supervision. In both types of education, the teachers are concerned with creating the contents of the curriculum, school assignments and appropriate tests that fit the learning situation. The results of this question differ with the results of the Quran study (2021), which indicated that there were differences due to the type of kindergarten in favor of private kindergartens, and the results of Madani (2021), which indicated that there were differences due to the type of kindergarten and in favor of government kindergartens.

\subsection{Specialization Variable}

Table (6) shows that there are statistically significant differences in the responses of early childhood teachers attributable to specialization in the fields and in the total degree, and the differences came in favor of nonkindergarten majors. The researchers attribute this to the presence of a number of respondents to the questionnaire 
who specialize in information technology, and they possess the skills that aim to motivate children to interact with the educational materials provided, encourage experimentation, in addition to developing a love of discovery instead of memorization, and break monotony and boredom in the educational process and wandering in thinking during their presence in the classroom.

\subsection{Qualification Variable}

Table (6) shows that there are no statistically significant differences in the responses of early childhood teachers due to qualification on the domains and on the total score. The two researchers attribute to the fact that female teachers have a major and important role, even if the educational qualifications differ. The early childhood teacher is the one who raises the child in this sensitive and ambitious stage in building the child's personality and seeks to achieve the educational goals required by the curriculum, taking into account the age characteristics of this stage regardless of qualification. This study is combined with the Hamadna study (2020), which indicated that there were no statistically significant differences due to the educational qualification variable.

\subsection{Experience Variable}

Table (6) shows that there are no statistically significant differences in the responses of early childhood teachers due to experience on the domains and on the total score. The researchers attribute this result to the fact that early childhood teachers have a central role in achieving sound education, due to its creative abilities and capabilities, and the ability to enlighten and discover the child and his inner energies. Early childhood programs and their daily activities and educational goals can only be accomplished by a specialized teacher who is aware of the requirements of early childhood and its basic needs, who understands the role of education in the kindergarten stage with experience (more than 10 years).

The results of the third question: Are there statistically significant differences at the significance level $(\alpha \geq .05)$ between the average responses of early childhood teachers due to the cultural context variable for the quality of distance education (Kingdom of Saudi Arabia - Jordan)?

The t-test was used to show the significance of the differences between the arithmetic averages among the average responses of early childhood teachers due to the cultural context variable of the quality of distance education (Kingdom of Saudi Arabia - Jordan and Table (7) shows that:

Table 7. T-test to show the significance of the differences between the arithmetic averages among the average responses of early childhood teachers due to the cultural context variable of the quality of distance education (Kingdom of Saudi Arabia - Jordan)

\begin{tabular}{|c|c|c|c|c|c|c|c|}
\hline Field & Country & $\begin{array}{l}\text { The } \\
\text { number }\end{array}$ & Averages & $\begin{array}{l}\text { Standard } \\
\text { deviations }\end{array}$ & $\mathbf{T}$ & $\begin{array}{ll}\begin{array}{l}\text { Degrees } \\
\text { freedom }\end{array} & \text { of } \\
\end{array}$ & Indication \\
\hline \multirow[t]{2}{*}{ First } & $\begin{array}{l}\text { Saudi } \\
\text { Arabia }\end{array}$ & 103 & 2.36 & .503 & \multirow[t]{2}{*}{-} & \multirow[t]{2}{*}{155} & \multirow[t]{2}{*}{.000} \\
\hline & Jordan & 54 & 2.65 & .356 & & & \\
\hline \multirow[t]{2}{*}{ Second } & $\begin{array}{l}\text { Saudi } \\
\text { Arabia }\end{array}$ & 103 & 2.05 & .676 & \multirow[t]{2}{*}{$\begin{array}{l}- \\
2.764-\end{array}$} & \multirow[t]{2}{*}{155} & \multirow[t]{2}{*}{.006} \\
\hline & Jordan & 54 & 2.35 & .649 & & & \\
\hline \multirow[t]{2}{*}{ Third } & $\begin{array}{l}\text { Saudi } \\
\text { Arabia }\end{array}$ & 103 & 2.22 & .631 & \multirow[t]{2}{*}{-} & \multirow[t]{2}{*}{155} & \multirow[t]{2}{*}{.003} \\
\hline & Jordan & 54 & 2.53 & .603 & & & \\
\hline \multirow[t]{2}{*}{ Fourth } & $\begin{array}{l}\text { Saudi } \\
\text { Arabia }\end{array}$ & 103 & 1.94 & .684 & \multirow[t]{2}{*}{4.195} & \multirow[t]{2}{*}{155} & \multirow[t]{2}{*}{.000} \\
\hline & Jordan & 54 & 2.40 & .581 & & & \\
\hline \multirow[t]{2}{*}{ Fifth } & $\begin{array}{l}\text { Saudi } \\
\text { Arabia }\end{array}$ & 103 & 2.38 & .628 & \multirow[t]{2}{*}{-} & \multirow[t]{2}{*}{155} & \multirow[t]{2}{*}{.021} \\
\hline & Jordan & 54 & 2.61 & .515 & & & \\
\hline \multirow[t]{2}{*}{$\begin{array}{l}\text { Total } \\
\text { marks }\end{array}$} & $\begin{array}{l}\text { Saudi } \\
\text { Arabia }\end{array}$ & 103 & 2.21 & .524 & \multirow[t]{2}{*}{-} & \multirow[t]{2}{*}{155} & \multirow[t]{2}{*}{.000} \\
\hline & Jordan & 54 & 2.53 & .456 & & & \\
\hline
\end{tabular}


Table (7) shows that there are statistically significant differences in the responses of early childhood teachers due to the cultural context on the domains and on the total score and in favor of Jordan. The researchers attribute this result to the fact that Jordan is one of the advanced countries in the e-learning system, which emphasizes that development efforts must focus on revolutionizing the educational system through tight policies and strategies that include information and communication technology at the core of the educational process, and make it a base for upgrading in education, and as a tool to stimulate creativity and excellence. The Ministry of Education started during the nineties of the last century to hold specialized courses in the field of technology for teachers free of charge, such as the ICDL course, which led to their gaining good experience

\section{Recommendations}

In light of the results of the study, the researchers recommend the following:

a) Support and encourage teachers to use electronic platforms through virtual classes, online exams and assignments.

b) Implementation of training courses for teachers and parents that fit the current reality of distance education.

c) Creating a platform for sharing distinguished practices in distance education among early childhood teachers.

d) Conducting more studies in this field, especially those related to the effectiveness of distance education on children's learning in familiar and unfamiliar contexts.

\section{Authors' Information}

${ }^{1}$ School of Education, Oxford Brookes University, UK

Dr. Ibrahim Abdulkareem Alhussein KSA. UNESCO Regional Center for Quality and Excellence in education. E-mail: i.alhussein@rcqe.org

Dr. Aidah Deeb Mohammad KSA. Associate Professor, Department of Kindergarten- King Faisal University. Email:amohammad@kfu.edu.sa

Correspondence: Mona Al-Zahrani, School of Education, Oxford Brookes University, UK. Email:dralzahrani13@gmail.com

\section{References}

Al- Sawalh, A. S. (2020). The effectiveness of using the e-book in developing the language skills of kindergarten students. Educational Science Studies, University of Jordan, 47(2), 601-616.

Algharib, H. (2010). E-Education, Cairo, Sinai Publishing House.

Al-Musa, N. A. (2018). Indicators of the Quality of Public Education in Saudi Arabia. Future of Arab Education Magazine, 15(114),133-176.

Al-Quraan, R. N. (2021). The reality of e-learning in light of the Corona pandemic in kindergartens in the Directorate of Education of Irbid I, unpublished master's letter, Jerash University, Amman Jordan.

Al-Rashid, M. A. (2018). Degree of possession of digital learning by kindergarten teacher and its trends towards sustainability. Journal of the Islamic University of Educational and Psychological Studies, 26(3), 277-232.

Alshaikh, K., Maasher, S., Bayazed, A., Badri, S., \& Fakieh, B. (2021). Impact of COVID-19 on the educational process in saudi arabia: A Technology-Organization-Environment framework. Sustainability, 13(13), 7103. https://doi.org/10.3390/su13137103

Ansari, R. A. H. (2020). Teacher roles in meeting the challenges of achieving the quality of education. Virtual International Conference on the Future of Digital Education in the Arab World, p. 732-247.

Ashi, A., \& Broras, F. (2018). Strategies for activating the e-learning system at the university. Journal of Humanities,18(2), 92-107.

Bawaneh, A. K. (2021). The satisfaction level of undergraduate science students towards using e-learning and virtual classes in exceptional condition COVID-19 crisis. Turkish Online Journal of Distance Education, 22(1), 52-65. https://doi.org/10.17718/tojde.849882

Belay, D. G. (2020). COVID-19, distance learning and educational inequality in rural ethiopia. Pedagogical Research, 5(4). https://doi.org/10.29333/pr/9133

Best, J. W. (1981). Research in education. Englewood Cliffs, N. J: Prentice-Hall. 
Burdina, G. M, Krapotkinal, I. E, Nasyrova L. G. (2019). Distance learning in Elementary School Classrooms: An Emerging Framework For Contemporary Practice. International Journal of Instruction, 12(1), 1-16. https://doi.org/10.29333/iji.2019.1211a

Foti, P. (2020). Resarch in distance learning in greek kindergarten school during the pandemic of covid-19 possibilities dilemmas limitation. European Journal of Open Education and E-Learning, 5(1)

Hamada, H. S. (2020). Trends of teachers and teachers of the Schools of the Bani Kanana Brigade towards the effectiveness of the SpaseNoor platform used under the Corona Covid pandemic - 19 Palestinian. Journal of Open Education and E-Learning, 9(15), 59-69.

Madini, M. I. (2021). The most important challenges facing kindergarten teachers with distance education in Jeddah. International Journal of Humanities and Social Sciences, (19), 269-297.

O'Keefe, L., Dellinger, J. T., Scragg, B., Amelina, N., \& Mathes, J. (2020). The state of online learning in the kingdom of saudi arabia: A COVID-19 impact study for K-12. Online Learning Consortium, Inc, PO Box 1238, Newburyport, MA 01950. Retrieved from ERIC Retrieved.

Ramadan, M. J. M. (2020). The role of distance education in solving the problems of the emerging Corona epidemic. Educational Journal, Sohag University, (77), 1531-1543.

\section{Copyrights}

Copyright for this article is retained by the author(s), with first publication rights granted to the journal.

This is an open-access article distributed under the terms and conditions of the Creative Commons Attribution license (http://creativecommons.org/licenses/by/4.0/). 